Hoenderbos, W., Hooimeijer, P., \& Hoorn, van, F. (1986). Urban housing and labour markets in transition: research in progress. Tijdschrift voor Economische en Sociale Geografie, 417-422. 


\title{
URBAN HOUSING AND LABOUR MARKETS IN TRANSITION: RESEARCH IN PROGRESS
}

by

\author{
WOUTER HOENDERDOS*, PIETER HOOIMEIJER* \& FRANK VAN HOORN*
}

Utrecht, The Netherlands

Urban change has become a very central issue in the study of human geography. As the processes involved are of a complex nature, this field has become highly fragmented. Many researchers study various aspects of urban housing and labour markets which can be considered the primary agents of urban change. Because of its size and its clear focus on these phenomena, the Department of Geography at the University of Utrecht carries out a wide spectrum of urban research (Ottens \& Ter Welle-Heethuis 1983, Hoenderdos, Van Lindert \& Verkoren 1983).

On the occasion of the 350th anniversary of the University of Utrecht, a seminar was organised, entitled 'Urban Housing and Labour Markets in Transition', in which junior researchers presented their work and discussed it with senior researchers active in this field. The main goal of the seminar was to gauge the relevance of the focus of the research, to evaluate its theoretical underpinnings, and to check the aptness of the research methodologies chosen. A secondary aim was to counteract the tendency toward fragmentation by stimulating an awareness of how the various research themes are related to each other.

Three broad topics were chosen.

1) The changing demographic composition of the population in Western countries has affected housing markets. Besides the

\footnotetext{
* Department of Geography, University of Utrecht, P.O. Box 80.115, 3508 TC Utrecht, The Netherlands.
}

Received, October 1986; revised, December 1986. post-war baby boom and the dropping fertility rates in the sixties and seventies, the changing patterns of household formation and dissolution have also had an impact on housing markets.

2) There is a reversal of the trend toward urbanisation, which has consequences for the yrban structure in the Netherlands. This reversal draws attention to the relation between housing and labour markets.

3) The structural dimensions of the labour markets in developing countries influence the scope of survival strategies of the urban poor.

This contribution poses some general conclusions for each of these themes.

\section{Modelling the housing market}

The contribution of geography to housing market research has traditionally focussed on the analysis and explanation of residential mobility and housing choice. Early studies (Rossi 1955, Abu-Lughod \& Foley 1960) already showed that life-cycle factors play a decisive role in the explanation of housing demand. When the technical equipment to analyse categorical data was introduced in geography, more formal analyses of present trends were made. Using a multi-variate approach, these data models (Willekens 1984) have substantiated the importance of age and household composition to the residential mobility process.

The models have revealed that at the aggregate level, the changing demographic composition will have an inexorable effect on the functioning of the housing market. The 
growth in the number of the elderly, who tend to have very low mobility rates, will increase the pressure on the attractive segments of the housing market (Hooimeijer, Clark \& Dieleman 1986). The reduction in the number of young households will lead to a decrease in the production of new housing, making adjustments in the existing stock imperative. The growing diversity of households has given rise to an increasing diversity of life courses and has rendered the traditional life cycle obsolete (Stapleton 1980).

In order to assess the impact of these socio-demographic trends they must be quantified. Simulation models provide the means for such an assessment. Two simulation models were presented during the seminar: one for the Amsterdam region (Rima \& Van Wissen 1986) and one on the national scale (Linde \& Hooimeijer 1986). Both models simulated the impact of demographic change and of changes in the composition of households on the demand for housing, starting from the assumption that changes in household composition are among the main factors which trigger the housing adjustment process. Without going into the mathematics, the operation of the models is relatively straightforward. First, using transition matrices, changes in households (e.g., formation, expansion, reduction and dissolution) are modelled for a short interval of time (for periods of a year). Next, using a nested multinomial logit approach, the shifts in the housing situation are simulated on the basis of these demographic transitions and on the basis of the housing situation prior to these events.

This dynamic macro-simulation approach has a clear advantage over many other housing demand models which use stateprobabilities to deal with cohort effects. As these models are fully demand-driven, either the model has to be extended to include supply or the amplifying assumption must be made that supply will meet demand. The second option is unsatisfactory, both from a theoretical and from a planning point of view. Existing demand for housing is bound to be influenced by present market conditions. Housing demand is not only determined by preferences, but also by opportunities and constraints. Although these concepts may be differentiated, it is hard to separate them analytically.

The issue is further complicated by the fact that these three aspects are influenced by changes in the context of the housing system. Shifts in housing preferences correspond to socio-cultural trends, and constraints may be altered by economic development. Demographic developments change not only the aggregate demand patterns, but also the supply, as most opportunities are created by households moving to another dwelling. Changes in housing policies are also closely tied to the variations in the context.

From a geographical point of view, not only temporal changes are of interest. Variations in the spatial context may completely alter the structure of the supply. This pertains not only to the supply of new housing, involving many actors, differing interests and complicated policy interventions, but also to the existing stock. The study of the supply side of the Vienna housing market presented at the seminar (Schönhofer 1986) showed the constraints imposed on the actions of private landlords by means of security of tenure and rent control. Within these constraints the landlord faces a complex decision when a vacancy arises in his property. He can choose to demolish, improve or offer it for occupancy immediately. The latter two options entail a subsequent choice: to rent, sell or convert the property to other uses. The profitability of each option cannot be calculated directly on the basis of demand, as it is also influenced by diverse government subsidies.

The study of decision-making among public landlords is more complicated, as economic considerations play an even smaller role. The sale of public housing is a perfect example. In contrast to the British case, this type of tenure conversion has been sporadic in the Netherlands. Permission to sell has become an issue. It requires consensus at three different levels of governmental jurisdiction, making the sale of public housing a rather rare and spatially highly concentrated event (Boelhouwer 1986).

Both the supply and demand of housing are dynamic and complex. Supply and demand are so closely intertwined that any attempt to model either side separately is doomed to be inadequate. The real bottleneck in housing market research is how to model the intricate phenomenon known as 'the market-clearing process'. The price mechanism is not a viable instrument to balance supply and demand. Market-clearing in the housing market has strong parallels to 
that in the labour market; it occurs by means of vacancy chains. If the models can elucidate the complex interrelations between supply and demand, they will prove to be more appropriate from a theoretical point of view, as well as more applicable in a planning context. Therefore market-clearing models should be seen as the major research challenge in this field.

\section{(Sub)urbanization and urban structure}

The discussion of the (modelling of) the processes in the housing market left the spatial distribution of the supply and the demand largely unstudied. Two elements discussed above are, however, of particular importance to this distribution. First, the changes of the structure of households show a clear trend towards a substantial increase of small households; a large share of these might be interested in a central city location. Secondly, the supply of new housing is highly institutionalised and strongly influenced by public subsidies. The housing policy is increasingly directed towards the central cities.

In conjunction these developments may lead to a reversal of existing trends in urbanization. The policy of the city of Amsterdam is intended to stop the selective population decrease by building large numbers of new housing for families. This policy seems to be successful, not in the least due to the support given by the national government after having abandoned the New Town policy which it so vigorously advocated during the late sixties and the seventies (Kok 1986). However, in the long run such policies can only be successful if demand is also directed towards the city. If this is not the case, adjoining municipalities may be more successful in attracting inhabitants, and long-term vacancies may arise in the city. At this moment, however, this is more of a problem for the surrounding New Towns than for the traditional donor city.

The trends demonstrate that it is time to reconsider the traditional ideas about urbanization. The renewed preference for central city housing does affect the process of suburbanization. Housing may lose its function as a main structuring element in this process. Instead more attention should be given to the deconcentration of employment and services from the central city. The spatial parameters of this process may become the critical elements in the differentiation among suburbs in the future (Jansen 1986).

These trends and their consequences call for a new approach to the explanation of redistribution of an urban population over suburban areas. It is generally assumed that short-distance relocation of firms only changes the direction of commuting patterns. However, an empirical study (Doorn 1985) showed various reactions by employees to the suburbanization of their employment and showed that not only socio-economic, but also demographic characteristics play a role. Depending on the age, sex, educational level and occupational skill of the employee, the decision to commute, move or quit the job may be very different (Van Rietbergen 1986). The theoretical foundations in this field of research are rather weak. The study of the position of the households in the housing market and the labour market should be integrated. Micro-simulation models employing life-history data could be a promising avenue toward this integration. But also the spatial and social context may be very influencial. In Great Britain, for instance, the housing situation is an important factor in determining the employment opportunities of young adults (Sullivan 1986). The crucial role of the context also stands out in studies of developing countries, where the labour market position is of overriding importance.

\section{Labour markets in developing countries}

Urban change in developing countries is strongly influenced by economic factors in rural and urban areas. In contrast to the situation in developed nations, people in developing countries are much more likely to follow employment opportunities and to move from areas where employment/income opportunities are hard to find or even absent. Cities are attractive to many migrants in search of work and, generally speaking, work is the main objective of many migrants moving to cities. Housing is - at least in the beginning of migrants' urban existence - much less important. This is not only true for migrants, but also for the majority of the urban population. Therefore, it is not surprising that studies of urban labour markets in developing countries concentrate on job opportunities in general and on the mechanisms and processes taking place within those labour markets. Less attention is given to other aspects such as the relationship between job career and housing career, or hous- 
ing as a function of job type or place of work.

Within this wider framework, the role of the political system is crucial to an understanding of the role of employment. An example taken from the small-scale textile industry in Nicaragua (Laenen 1986) shows how the demand for labour is influenced by certain structural determinants. In this case, the role of state policy is evident. The study classifies the small-scale textile industry in three types on the basis of organizational structure. The rate of increase of employment in production cooperatives and the (stateowned) collectives was very strong between the first visit in 1983 and the second one in 1985. This growth was mainly due to the preferential position given by the government to those types of production organization. Cooperatives and collectives enjoy more facilities for obtaining (state-delivered) material, credit, technical assistance and outlets than do privately owned enterprises. As a result, employment in privately owned enterprises lagged behind. In this case, therefore, among the external conditions of running an enterprise, government strategy is a critical factor as it also influences the absorption of labour in industry. Whether or not we can generalize from the Nicaraguan case, it is noteworthy that of all manufacturing employment in all developing countries, smallscale industry is the most important source of labour absorption. And the external factors most often considered to hamper the functioning of small enterprises are access to credit and product markets.

However important it is to identify structural factors, researchers should not be tempted to forsake behavioural analysis, as the effects of structural changes will be experienced at the individual level. An analysis of the supply side of the labour market in Ciudad Juárez, Mexico, showed the relations between three labour status indices: employment status, income status and economic status. Employment status, based on job security and income guarantees, is divided in turn into three broad categories of workers, including 'casual workers'. Contrary to the generally accepted view, 'casual workers' cannot be considered as equal to 'casual poor' (based on income level/income status). When analysing individual job changes in terms of employment status, it seems that in Ciudad Juárez the labour market is strongly segment- ed in the sense that casual workers often change jobs (even change occupation and/or economic sector), but 'upward mobility' in employment status is rarely achieved. Although a change of job generally entails a change in income, this change is rarely an improvement in income (Gelderloos 1986).

The study of survival strategies of poor people must take a flexible approach. It must not be restricted by using pre-defined sectors or occupational groups, let alone Europeanbased socio-economic categories or social status indices. Job careers do exist, though in an entirely different way than expected. This is why it is so hard to define an informal sector on the basis of occupational or individual characteristics or, on the demand side, on enterprise characteristics. In reality, the complex interplay of persons, activities and occupations appears to be one huge pool of possibilities and opportunities. However attractive it may seem, it is wishful thinking to expect to define such a 'segment' of the labour market, let alone its relation to a similarly complex housing market.

\section{Conclusions}

The seminar was a clear illustration of the fact that 'the study of spatial phenomena often takes the back seat to the analysis of the dynamics of the phenomena themselves' (Van Weesep 1986). However it also illustrated that many isolated research projects are really the study of two sides of the same coin. Concentration on micro-behavioural studies has certainly advanced theoretical insights in these complex phenomena, but it has also resulted in a fragmentation of geographical knowledge. It is hard to integrate the findings of research on different aspects of urban reality into a comprehensive picture. Moreover, the various factors operating in the urban housing and labour markets, and thereby in the urban structure as a whole, originate at different levels of analysis.

These problems become most apparent the moment we attempt to construct models. The theoretical weaknesses and the lack of a clear relation to the planning context then become manifest. Without advocating large-scale urban development models, the importance of integrated models as a unifying framework could be stressed. Models can contribute to theory-building as they force us to produce structured knowledge. Apart from this they have a didactic value in communicating the 
essential features of development and they can therefore be very helpful in structuring the dialogue between researchers and policymakers (Tinbergen 1981).

The integration of different kinds of models is certainly a desirable alternative to the current scattering of existing research. This, however, is out of reach for individual

\section{Acknowledgement :}

We would like to express our appreciation to the Netherlands Organisation for the Advancement of Pure

\section{List of participants:}

P. J. Boelhouwer*, L. E. Borgegard (Gavle, Sweden), L. S. Bourne (Toronto), J. Buursink (Nijmegen), W. A. V. Clark (Los Angeles), J. B. S. Conijn (Delft), F. M. Dieleman*, P. K. Doorn (Leiden), A. S. Fotheringham (Gainesville), G. Gelderloos*, W. H. Hoenderdos*, P. Hooimeijer*, F. J. J. H. van Hoorn*, D. G. Janelle (London, Canada), A. W. P. Jansen*, R. J. Johnston (Sheffield), G. A. van der Knaap (Rotter-

\section{References:}

AbU-Lughod, J. L. \& M. M. Foley (1960), Consumer Strategies. In: N. N. Foote, et al., Housing Choice and Housing Constraints. New York: McGraw-Hill.

Boelhouwer, P. J. (1986), The Sale of Public Housing in the Netherlands. Paper presented at the seminar 'Urban Housing and Labour Markets in Transition'. Utrecht.

Doorn, P. K. (1985), Problems of Categorisation of Actors and the Interrelation of Labour Mobility and Residential Mobility. Tijdschrift voor Economische en Sociale Geografie 76, pp. 163-179.

Gelderloos, G. (1986), Casual Work and Poverty in Ciudad Juárez, Mexico: A Labour Market Analysis. Paper presented at the seminar 'Urban Housing and Labour Markets in Transition'. Utrecht.

Hoenderdos, W. H., P. van Lindert \& O. Verkoren (1983), Residential Mobility, Occupational Changes and Self-Help Housing in Latin American Cities. Tijdschrift voor Economische en Sociale Geografie 74, pp. 376-386.

Hooimeijer, P., W. A. V. Clark \& F. M. Dieleman (1986), Households in the Reduction Stage: Implications for the Netherlands' Housing Market. Housing Studies 1, pp. 195-210.

JANSEN, A. W. P. (1986), Differentiation among and Urbanization of the Suburbs. Paper presented at the seminar 'Urban Housing and Labour Markets in Transition'. Utrecht.

KoK, J. B. (1986), Evaluation of the 'Compact City' Policy in Amsterdam. Paper presented at the seminar 'Urban Housing and Labour Markets in Transition'. Utrecht.

LAENEN, A. (1986), Handicraft and Small Industry in Nicaragua. Paper presented at the seminar 'Urban Housing and Labour Markets in Transition'. Utrecht.

Linde, M. A. J. \& P. Hoormeijer (1986), Demographic Developments and the Housing Market: A Dynamic Macro-simulation up to the Year 2000. Paper presented at the seminar 'Urban Housing and Labour Mar- researchers. Conceivably, the formation of research teams could help to overcome this problem. The participation of planning authorities, not just financially but also in terms of manpower, could help to bridge the gap between academic research and policy implementation.

Research (zwo) for the grant which made the organisation of the seminar possible.

dam/The Hague), J. B. Kok (Amsterdam), A. Laenen*, M. A. J. Linde*, H. F. L. Ottens*, A. Portes (Baltimore), A. van Rietbergen*, A. Rima (Amsterdam), H. Schönhofer (Vienna), M. de Smidt*, O. Sullivan (London), H. J. P. Timmermans (Eindhoven), O. Verkoren*, J. van Weesep*, F. J. Willekens (Utrecht/The Hague)

* Department of Geography, University of Utrecht.

kets in Transition'. Utrecht.

Ottens, H. F. L. \& J. G. P. ter Welle-Heethuis (1983), Recent Urban Research at Utrecht. Tijdschrift voor Economische en Sociale Geografie 74, pp. 387-396.

RIETBERgen, A. VAN (1986), Approaches to Residential and Labour Mobility: Forthcoming Research in Neglected Fields. Paper presented at the seminar 'Urban Housing and Labour Markets in Transition'. Utrecht.

Rima, A. \& L. VAN Wissen (1986), Household Dynamics and Housing Demand: an Empirical Analysis for the Amsterdam Region. Paper presented at the seminar 'Urban Housing and Labour Markets in Transition'. Utrecht.

Rossi, P. (1955), Why Families Move. Glencoe, Ill: The Free Press.

Schönhofer, H. (1986), The Vienna Housing Market Model: The Supply Side. Paper presented at the seminar 'Urban Housing and Labour Markets in Transition'. Utrecht.

Stapleton, C. M. (1980), Reformulation of the Family Life-Cycle Concept : Implications for Residential Mobility. Environment and Planning A 12, pp. 1103-1118.

Sullivan, O. (1986), The Relationship between Housing and Unemployment among Youth Adults in Great Britain. Paper presented at the seminar 'Urban Housing and Labour Markets in Transition'. Utrecht.

IINBERgen, J. (1981), The Use of Models: Experience and Prospects. American Economic Review 71, 6, pp. 17-29.

WEESEP, J. VAN (1986), Condominium: A New Housing Sector in the Netherlands. Ph.D. thesis, University of Utrecht.

Willekens, F. J. (1984), Spatial Policy and Demographic Research Opportunities. In: H. TER HEIDE \& F. J. Willekens, Demographic Research and Spatial Policy. London: Academic Press. 